\author{
저수온기 넙치 치어에 있어서 발효마늘분말의 사료 내 첨가가 면역반응, \\ 혈액성분 및 주요 어병세균에 대한 질병저항성에 미치는 영향 \\ 김성삼 ${ }^{1} \cdot$ 송진우 ${ }^{1} \cdot$ 임세진 ${ }^{1} \cdot$ 정준범 $^{1} \cdot$ 전유진 $^{1} \cdot$ 여인규 $^{1} \cdot$ 이경준 $^{1,2 *}$ \\ ${ }^{1}$ 제주대학교 해양의생명과학부, ${ }^{2}$ 제주대학교 해양과환경연구소
}

\title{
Effects of Dietary Supplementation of Fermented Garlic Powder on Immune Responses, Blood Components, and Disease Resistance against Principal Fish Disease of Juvenile Olive Flounder, Paralichthys olivaceus in Low Temperature Season
}

Sung-Sam Kim ${ }^{1}$, Jin-Woo Song ${ }^{1}$, Se-Jin Lim ${ }^{1}$, Joon Bum Jeong ${ }^{1}$, You-Jin Jeon ${ }^{1}$, In-Kyu Yeo ${ }^{1}$ and Kyeong-Jun Lee ${ }^{1,2} *$

${ }^{1}$ Faculty of Marine Biomedical Science, Jeju National University,

${ }^{2}$ Marine and Environmental Research Institute, Jeju National University

\begin{abstract}
We report non-specific immune responses and disease resistance against Vibrio anguillarum, Streptococcus iniae and Edwardsiella tarda by dietary supplementation of fermented garlic powder (FGP) in olive flounder for the first time. Four isonitrogenous $(45 \%$ crude protein) and isocaloric $(17.1 \mathrm{MJ} / \mathrm{kg})$ diets were formulated to have $0 \%, 0.5 \%, 1 \%$ and $2 \%$ of the FGP (G-0, G-0.5, G-1 and G-2). The experimental diets were fed to juvenile olive flounder averaging $23.4 \mathrm{~g}$ in triplicate groups $(90$ fish/group) in a flow-through system. After a five-week feeding trial, healthy fish with similar sizes from each tank were selected and injected with $1 \mathrm{ml}$ of three bacteria each to evaluate disease resistance of the fish. During the 5-week feeding trial, the weight gain, specific growth rate, feed conversion ratio, protein efficiency ratio, and survival of the fish were not significantly affected by the experimental diets. However, feed intake was significantly lower $(\mathrm{P}<0.05)$ in the fish fed the G-2 diet compared with the control group. Hemoglobin, myeloperoxidase activity, cholesterol and HDL-cholesterol were not different between the dietary groups. However, hematocrit, nitroblue tetrazolium (NBT) activity, and lysozyme activity were increased $(\mathrm{P}<0.05)$ with an increment of dietary FGP. Plasma triglyceride of the fish fed the G-0.5 diet was significantly lower than that of fish fed the control diet. The cumulative mortality was lower in the fish fed diets containing FGP compared with the control group in the challenge test except for the bacteria Edwardsiella tarda. The results in this study indicate that dietary supplementation of FGP can enhance the non-specific immune responses and disease resistance of olive flounder against $V$. anguillarum and $S$. iniae.
\end{abstract}

(Key words : Olive flounder, Fermented garlic powder, Non-specific immune response, Challenge test)

$$
\text { 서 론 }
$$

어류는 물이라는 서식환경의 특수성에 의해 항상 병원성 미생물 에 노출되어 있어 어류의 입, 아가미, 피부 등으로 감염되어 전파 되므로 다른 생물에 비해 감염기회가 높아 발병비율이 높은 것으로 알려져 있다. 특히, 국내 양식산업의 경우 생산성 향상을 위한 밀 식, 과다한 사료 투여 등으로 인한 양식환경의 악화, 내병성 저하 및 감염기회의 증대로 다양한 어류질병이 발생함에 따라 항생제의 사용량과 빈도수도 점차 증가하고 있다. 과다한 항생제 사용의 증
가는 양식어류의 치료를 어렵게 할 뿐만 아니라 인근 양어장으로 약제 내성균의 확산을 초래하게 되고 나아가 수질환경을 오염시켜 생태학적으로 큰 문제점을 야기 시킬 수 있다. 따라서 최근 많은 국가에서 항생제 사용을 금지하고 있고 그 사용량과 식품에서의 잔 류허용량 규제가 더욱 엄격해지고 있으며, 최대잔류허용기준 (MRL, maximum residue level)을 설정하여 규제하고 있다. 이에 따라 항생제 대체방안으로 부작용이 없는 천연물질을 사료첨가제로 개발 하여 양식어류의 면역력 및 건강을 증진시키기 위한 양식산업의 기 능적 브랜드화가 시도되고 있다(Kim et al., 2006).

* Corresponding author: Dr. Kyeong-Jun Lee, Faculty of Marine Biomedical Science, Jeju National University, Jeju 690-756, Republic of Korea. Tel: 82-64-754-3423, Fax: 82-64-756-3493, E-mail: kjlee@jejunu.ac.kr 
마늘(Allium sativum L.)은 백합과(Lilliaceae) 파속(Allium)에 속하는 비늘줄기채소이다. 마늘이 가지는 여러 생리활성 성분으로 는 alliin과 allicin이 있으며 (Stoll and Seeback, 1951), 이외에도 diallyl sulfide 및 diallyldisulfide와 같은 화합물이 있다. 이 성분 들은 마늘의 자체효소인 allinase에 의해 alliin이 allicin으로 분해 되고 allicin은 다시 diallyl thiosulfinate와 diallyl disulfide 및 sulfide류로 분해된다(Mazelis and Crews, 1968). 결국 alliin 분 해과정 중 생성된 allicin의 thiosulfinate기가 $\mathrm{SH}$ 기와 강하게 반응 하여 다양한 약리효능을 보이는 것이다(Small et al., 1947). 마늘 의 약리효능으로는 면역증진효과(Mun et al., 2004), 항산화효과 (Shin et al., 2009; Chung and Kim, 2008), 아질산염 소거능 (Shin et al., 2009; Chung and Kim 2008), 항균효과(Wi, 2003; Kim et al., 2004; Kim et al., 2005), 항암작용 (Shon et al., 2001; Mun et al., 2004; Kim et al., 2005; Park et al., 2005), 항고혈압(Chun and Paik, 1997; Kim et al., 2005), 항곰팡이 (Kim et al., 2005) 및 저혈당작용 (Chi et al., 1982) 등이 보고 되었다.

우리나라의 대표적 양식 어종인 넙치 (Paralichthys olivaceus)는 고밀도 양식으로 인한 여러 질병의 발생으로 경제적 손실을 비롯한 많은 어려움을 겪고 있다. 넙치 양식산업에서 대표적인 주요 세균 성질병에는 Vibrio anguillarum, Streptococcus iniae 및 Edwardsiella tarda 등이 있다.

본 연구에서는 마늘을 효과적으로 이용하기 위해서 착즙하고 남 은 마늘고형물 잔사를 고온발효균주를 이용하여 발효시켰다. 미생 물은 발효과정을 통해 성분을 분해하여 다른형태로 전환시키거나 분해효소를 만들며, 2 차 대사과정을 통해 여러 가지 새로운 형태의 물질을 생산한다. 따라서 우리 연구팀은 발효마늘분말이 가지는 다 양한 약리효능이 넙치 치어의 면역증강 및 주요 어병세균에 대한 저항성을 높일 수 있을 것이라는 가설을 세웠다. 하지만 넙치를 대 상으로 이 가설에 대한 in vivo 실험은 아직 수행되지 않았다. 따 라서 이번 연구는 마늘분말을 사료 내 농도별로 첨가하여 어류의 면역력, 혈액성분 및 주요 어병세균 3 가지에 대한 질병저항성에 미 치는 영향을 조사하고자 수행되었다.

\section{재료 및 방법}

\section{1. 마늘분말 제조}

발효마늘분말은 제주특별자치도 제주시 오등동에 위치한 아쿠아 그린텍(주)에서 자체 개발하여 제조한 것을 구입하여 사용하였다. 제조방법은 다음과 같다. 우선 서귀포시 대정읍에서 수확된 마늘을 구입하여 깨끗하게 세척한 후 착즙하였다. 그 후 착즙하고 남은 마 늘고형물 잔사를 바시러스계통 (Bacillus spp.)의 고온발효균주를 이용하여 고온발효시켜 마늘발효분말을 제조하였다. 본 연구에 사 용된 발효마늘분말의 일반성분 조성은 Table 1에 나타내었다.

\section{2. 실험사료}

Table 1. Proximate composition of fermentation garlic powder

\begin{tabular}{lc}
\hline Composition & Content \\
\hline \hline Dry matter $(\%)$ & 88.3 \\
Crude protein $(\%, \mathrm{DM})$ & 23.2 \\
Crude lipid $(\%, \mathrm{DM})$ & 6.3 \\
Crude ash $(\%, \mathrm{DM})$ & 2.8 \\
Carbohydrate $(\%, \mathrm{DM})$ & 12.4 \\
\hline
\end{tabular}

${ }^{1)}$ Carbohydrate $=100-(\%$ moisture $+\%$ protein $+\%$ lipid $+\%$ ash $)$.

총 4 개의 실험사료는 조단백질 함량과 에너지 수준이 각각 $45 \%$ 와 $17.1 \mathrm{MJ} / \mathrm{kg}$ 를 갖도록 동일하게 조성되었다. 본 실험에서 사용 된 실험사료의 조성과 일반성분 분석은 Table 2에 나타내었다. 발 효마늘분말의 사료 내 첨가함량이 각각 $0 \%, 0.5 \%, 1 \%$ 및 $2 \%$ 가 되도록 첨가하여 $(\mathrm{G}-0, \mathrm{G}-0.5, \mathrm{G}-1$ 및 $\mathrm{G}-2)$ 실험사료를 제조하였 다. 실험사료 제조는 우선 모든 사료원들을 파쇄기를 이용하여 분 말형태로 일정하게 만든 후, 각 사료원들을 사료조성표에 따라 정 확하게 무게를 재고 혼합하였다. 혼합 후 사료원 총량의 30 40\% 에 해당하는 증류수를 첨가하여 사료혼합기 (NVM-14-2P, Korea) 로 혼합 및 반죽하였다. 혼합반죽물은 소형쵸파기 (SMC-12, Korea) 를 이용하여 직경 $3 \mathrm{~mm}$ 크기로 압출 성형되었다. 제작된 실험사료 는 $-70^{\circ} \mathrm{C}$ 동결냉동 건조기에서 건조시켜, 시브 (Sieve)를 이용하 여 적당한 크기의 사료로 가공되었으며, 사료 공급 전까지 $-20^{\circ} \mathrm{C}$ 냉동고에 보관 후 실험에 사용되었다.

\section{3. 실험어 및 사육관리}

이번 실험에 사용된 실험어류는 제주도내 양식장에서 구입하여 제주대학교 소속 해양과환경연구소로 운송되어, 4주 동안 시판 배 합사료를 공급하면서 실험환경에 적응할 수 있도록 순치시킨 후 사 료공급실험에 사용되었다. 예비사육 후 넙치 치어(초기 평균무게: $23.4 \pm 1.04 \mathrm{~g}$ )는 총 12 개의 $110 \mathrm{~L}$ 원형 플라스틱 수조에 각 수조 당 30 마리씩 무작위로 선택되어 배치되었다. 사료공급실험은 실험 구당 3반복구를 두었으며, 사육수는 여과해수를 사용하여 2 3 $\mathrm{L} / \mathrm{min}$ 의 유수량이 공급되도록 조절하였고, 모든 실험수조에 용존 산소 유지와 원활한 사육수 순환을 위하여 에어스톤을 설치하였다. 광주기는 형광등을 이용하여 $12 \mathrm{~L}: 12 \mathrm{D}$ 조건으로 유지되었고, 전 실 험기간 동안 평균수온은 $16^{\circ} \mathrm{C}$ 에서 $18^{\circ} \mathrm{C}$ 범위로 넙치의 적정수온에 미치지 않는 저수온기로 자연수온에 의존하였다. 실험사료는 1 일 2 회(09:00와 16:00시)에 나눠서 어체중의 2 3\%로 제한급이를 하 였다. 성장률 측정은 2 주와 5 주 때 실시되었고, 측정 24 시간 전에 모든 실험어류를 절식시켰다. 사료공급실험은 총 5 주간 수행되었다.

\section{4. 샘플수집 및 분석}

5주간의 사료공급 실험 후, 어류의 최종 평균무게를 측정하여 증 
Table 2. Composition and proximate analysis of the experimental diets (\% of dry matter basis)

\begin{tabular}{|c|c|c|c|c|}
\hline \multirow{2}{*}{ Ingredients } & \multicolumn{4}{|c|}{ Diets } \\
\hline & $\mathrm{G}-0$ & G-0.5 & $\mathrm{G}-1$ & $\mathrm{G}-2$ \\
\hline White fish meal ${ }^{1)}$ & 45.0 & 45.0 & 45.0 & 45.0 \\
\hline Soybean meal ${ }^{1)}$ & 15.0 & 15.0 & 15.0 & 15.0 \\
\hline Fermentation garlic powder ${ }^{2}$ & 0.0 & 0.5 & 1.0 & 2.0 \\
\hline Wheat flour & 23.0 & 23.0 & 23.0 & 23.0 \\
\hline Yeast & 2.0 & 2.0 & 2.0 & 2.0 \\
\hline Vitamin mixture ${ }^{3)}$ & 1.0 & 1.0 & 1.0 & 1.0 \\
\hline Mineral mixture ${ }^{4)}$ & 1.0 & 1.0 & 1.0 & 1.0 \\
\hline Squid liver oil ${ }^{5)}$ & 8.0 & 8.0 & 8.0 & 8.0 \\
\hline Starch & 5.0 & 4.5 & 4.0 & 3.0 \\
\hline \multicolumn{5}{|l|}{ Proximate composition } \\
\hline Dry matter $(\%)$ & 83.4 & 82.1 & 79.3 & 78.1 \\
\hline Crude protein $(\%, \mathrm{DM})$ & 45.1 & 45.5 & 45.3 & 45.8 \\
\hline Crude lipid $(\%, D M)$ & 10.3 & 10.4 & 10.5 & 10.3 \\
\hline Crude ash $(\%, D M)$ & 12.4 & 12.5 & 12.3 & 12.5 \\
\hline Estimated energy $\left.(\mathrm{MJ} / \mathrm{kg} \mathrm{DM})^{6}\right)$ & 17.1 & 17.1 & 17.1 & 17.1 \\
\hline
\end{tabular}

1) Provided by Suhyup Feed Co. Ltd., Uiryeong, Korea.

2) Provided by Aqua Green Technology Co. Ltd., Jeju, Korea.

3) Vitamin premix (g/kg of mixture): L-ascorbic acid monophosphate, 100.0; DL-tocopheryl acetate, 20.0; thiamin hydrochloride, 4.0; riboflavin, 4.4; pyridoxine hydrochloride, 4.0; niacin, 30.0; D-pantothenic acid hemicalcium salt, 14.5; myo-inositol, 40.0; $\mathrm{D}$-biotin, 0.2; folic acid, 0.48; menadione, 0.2; retinyl acetate, 1.0; cholecalficerol, 0.05; cyanocobalamin, 0.01 .

4) Mineral mixture (g/kg of mixture): $\mathrm{MgSO}_{4} \cdot 7 \mathrm{H}_{2} \mathrm{O}, 80.0 ; \mathrm{NaH}_{2} \mathrm{PO}_{4} \cdot 2 \mathrm{H}_{2} \mathrm{O}, 370.0 ; \mathrm{KCl}, 130.0 ; \mathrm{Ferric}$ citrate, 40.0; $\mathrm{ZnSO}$. $7 \mathrm{H}_{2} \mathrm{O}$, 20.0; Ca-lactate, 356.5; CuCl, 0.2; $\mathrm{AlCl}_{3} \cdot 6 \mathrm{H}_{2} \mathrm{O}, 0.15 ; \mathrm{Na}_{2} \mathrm{Se}_{2} \mathrm{O}_{3} .0 .01 ; \mathrm{MnSO}_{4} \cdot \mathrm{H}_{2} \mathrm{O}, 2.0 ; \mathrm{CoCl}_{2} \cdot 6 \mathrm{H}_{2} \mathrm{O}, 1.0$.

5) Squid liver oil was purchased from E-Wha oil Co. Ltd., Pusan, Korea.

6) Estimated energy was determined by using values of $16.7 \mathrm{KJ} / \mathrm{g}$ protein or carbohydrate and $37.6 \mathrm{KJ} / \mathrm{g}$ fat for dietary ingredients (Garling and Wilson 1976).

체율(Weight gain), 사료섭취율(Feed intake), 사료전환효율(Feed conversion ratio), 일간성장률 (Specific growth rate), 단백질전환 효율 (Protein efficiency ratio) 및 생존율 (Survival)을 계산하였다. 최종 무게측정 후 각 수조마다 6마리의 어류를 무작위로 선별하여 2-phenoxyethanol 용액 $(100 \mathrm{ppm})$ 으로 마취시켜 헤파린 처리가 된 주사기를 사용하여 미부동맥에서 채혈을 하였다. 채혈 후, hematocrit, hemoglobin 및 nitroblue tetrazolium(NBT) activity 를 측정하였다. 분석 후, 남은 혈액은 myeloperoxidase (MPO) 및 lysozyme activity, triglycerol, cholesterol 및 HDL- cholesterol 분석을 위해 원심분리기 (Micro 17TR, Hanil Science, Korea)를 이용하여 $5,000 \mathrm{rpm}$ 으로 10 분간 원심분리하여 혈장을 분리하였다. 혈액을 채취하고 남은 어류는 일반성분 분석을 위해 $-50^{\circ} \mathrm{C}$ 저온 냉동고에 보관하였다.

\section{5. 실험사료 분석}

실험사료원 및 실험사료의 일반성분 분석은 $\mathrm{AOAC}(1995)$ 방법
에 따라 수분은 상압가열건조법 $\left(125^{\circ} \mathrm{C}, 3\right.$ 시간), 조회분은 직접회화 법 $\left(550^{\circ} \mathrm{C}, 12\right.$ 시간), 단백질은 자동 조단백 분석기 (Kejltec System 2300, Sweden)로 분석되었으며, 지방은 Folch et al. (1959)의 방 법에 따라 Soxhlet 추출장치 (Soxhlet Heater System C-SH6, Korea)를 이용하여 분석되었다.

\section{6. 혈액분석}

Hematocrit은 헤파린이 처리된 모세혈관채혈튜브(Micro- hematocrit Capillary Tubes)에 혈액을 채운 다음 고무판(Wax plates)에 세 운 후, 혈액진단원심분리기 (Micro Hematocrit VS-12000, Vision Scientific, Korea)에서 10 분간 원심분리하여 값을 측정하였다. 헤 모글로빈, 중성지방, 콜레스테롤 및 HDL-cholesterol 분석은 각각 의 시판 시약과 반응시킨 후 혈액생화학분석기 (Express plus system, Bayer, USA)를 이용하여 분석하였다. 헤모글로빈은 end point, 중성지질, 콜레스테롤, HDL-cholesterol은 kinetic 방법으로 분석되었다. 


\section{7. 면역학적 분석}

\section{(1) 대식세포 활성 분석}

혈액내의 대식세포 활성은 Kumari and Sahoo (2005)의 분석방 법을 응용하여 호흡폭발 동안의 호중구(Neutrophils)에 의한 oxidative radical 생성량을 측정하였는데 분석방법은 다음과 같다. 우선 혈액(전혈)과 NBT solution $(0.2 \%)$ 을 $1: 1$ 의 비율로 각각 50 $\mu \ell$ 씩 섞은 후 $25^{\circ} \mathrm{C}$ 에서 30 분 동안 반응시킨 후, $50 \mu \ell$ 를 glass tube에 옮긴 후, formazon 생성을 감소시키기 위해 dimethyl formamide를 $1 \mathrm{ml}$ 씩 넣는다. 그 후 $2,000 \times \mathrm{g}$ 에서 5 분 동안 원심 분리를 하여 최종적으로 상층액을 취한 후, $\mathrm{NBT}$ 의 감소되는 범위 를 분광광도계 (Genesys $10 \mathrm{UV}$, Rochester, NY, USA)를 사용하 여 최적의 흡광도인 $540 \mathrm{~nm}$ 에서 측정하였다. Blank는 dimethyl formamide를 사용하였다.

\section{(2) Myeloperoxidase activity 분석}

혈청 내 myeloperoxidase 활성은 Kumari and Sahoo(2005)의 방법을 기초로 분석하였다. 먼저 HBSS (Hanks balanced salt solution)를 96-well plates에 $80 \mu \ell$ 씩 분주한 다음 혈청 $20 \mu l$ 를 넣는다. 그 후 $20 \mathrm{mM} \mathrm{TMB}\left(3,3^{\prime} 5,5^{\prime}\right.$-tetramethyllbenzidine hydrochloride) 용액과 $5 \mathrm{mM} \mathrm{H} \mathrm{O}_{2}$ 용액을 넣는다. 2분간 반응시 킨 후 $4 \mathrm{M} \mathrm{H}_{2} \mathrm{SO}_{4}$ 용액을 $35 \mu \mathrm{l}$ 첨가한 후 microplate reader (Thermo, USA) $450 \mathrm{~nm}$ 에서 흡광도를 측정한다.

\section{(3) Lysozyme activity 분석}

혈청 내 lysozyme의 활성은 Yeh et al. (2008)의 분석방법을 바 탕으로 분석하였다. 먼저 $0.05 \mathrm{M}$ sodium phosphate acid buffer (pH 6.2)에 동결 건조된 Micrococcus lysodeikticus (Sigma, $\mathrm{USA}$ )를 첨가하여 $0.2 \mathrm{mg} / \mathrm{ml}$ 농도의 현탁액을 만든다. 현탁액 200 $\mu l$ 를 96-well plates에 분주하고, 어류에서 분리한 혈청 $10 \mu l$ 를 혼 합시킨 후, microplate reader (Thermo, USA)를 이용하여 $530 \mathrm{~nm}$ 에서 1 분과 6 분에 흡광도 값을 측정하였다. Lysozyme의 활성단위 는 분당 0.001 의 흡광도 감소를 나타내는 양으로 정의하였다.

\section{8. 공격실험}

5 주간의 성장실험 종료 후, 발효마늘분말이 넙치의 항병력에 미 치는 영향을 조사하기 위해 혈액샘플을 하고 남은 어류를 대상으로 병원성 세균 3종 Vibrio anguillarum (KCTC-2711), Streptococcus iniae (KCTC-3651) 및 Edwardsiella tarda (KCTC-3657)을 사용 하여 각각 복강주사를 통해 공격실험을 실시하였다. 병원성 세균 세 가지 균주는 각각 $\mathrm{TSA}$ 배지에서 $25^{\circ} \mathrm{C}$ 에서 24 시간 배양한 후 집균하였고, $\mathrm{PBS}$ 로 $1 \times 10^{5} \mathrm{cfu} / \mathrm{ml}$ 이 되도록 현탁하여 $0.1 \mathrm{ml}$ 씩 복
강주사 하였다. 5 주간의 사육실험 후 실험구 당 넙치 10 마리씩을 실험구로 사용하였다. 모든 그룹은 $24^{\circ} \mathrm{C}$ 로 수온을 유지하였으며, 23 일간 폐사를 관찰하였다.

\section{9. 통계학적 분석}

실험사료군의 배치는 완전확률계획법(Completely randomized design)에 따라 실시하였고, 분석결과는 SPSS (Statistical package for the social sciences, Version 12.0) 프로그램을 이용하여 One-way ANOVA로 통계 분석되었다. 데이터 값의 유의차는 Duncan's multiple test $(\mathrm{P} \leq 0.05)$ 로 비교되었다.

\section{결 과}

5 주간의 성장실험 결과, 사료 내 발효마늘분말의 첨가에 따른 성 장률, 일간성장률, 사료전환효율, 단백질전환효율 및 생존율에서는 모든 실험구에서 유의적인 차이를 관찰할 수 없었다 (Table 3). 사 료섭취율에서는 마늘분말의 첨가함량이 증가함에 따라 감소하다가 가장 높은 $2 \%$ 첨가구에서는 대조구 보다 유의적으로 낮은 사료섭 취율을 보였다. 하지만 $1 \%$ 첨가함량까지는 대조구와 유의적인 차 이를 보이지 않았다.

실험사료를 섭취한 넙치 치어의 혈액성분의 비교결과는 Fig. 1과 2에 나타내었다. 헤마토크릿은 모든 마늘분말 첨가구에서 대조구보 다 유의적으로 높았으며, 헤모글로빈은 경향적으로 모든 마늘분말 첨가구에서 높은 함량을 보였으나, 유의적인 차이를 보이지 않았다. 혈장 내 중성지질은 모든 마늘분말 첨가구에서 대조구와 비교하여 낮은 함량을 보였으며, $0.5 \%$ 첨가구에서 대조구보다 유의적으로 낮은 함량을 보였다. 하지만 콜레스테롤과 HDL-cholesterol 함량 은 모든 실험구에서 유의적인 차이가 없었다.

사료공급 24시간 후의 혈액을 채취하여 비특이적 면역반응을 분 석한 결과(Fig. 1), NBT activity는 모든 마늘분말 첨가구에서 대 조구보다 유의적으로 높은 활성을 보였다. 라이소자임 활성 또한 마늘분말 $0.5 \%$ 와 $1 \%$ 첨가구에서 대조구보다 유의적으로 높은 활 성을 보였다. 하지만 MPO activity는 모든 실험구에서 유의적인 차이를 보이지 않았다.

공격실험 결과, $V$. anguillarum을 사용하여 감염시킨 경우, 발효 마늘분말을 첨가하지 않은 대조구에서는 감염 후 4 일째에 $100 \%$ 의 누적폐사율을 보였지만, 마늘첨가 실험구 $(0.5 \%, 1 \%, 2 \%$ groups $)$ 에서는 각각 $40 \%, 30 \%, 40 \%$ 의 누적폐사율을 나타내었다(Fig. 3). 폐사어의 내부 장기로부터 세균을 분리하여 $V$. anguillarum에 감염되었음을 확인하였고, 궤양형성, 체색흑화, 지느러미 출혈 등의 V. anguillarum에 의한 전형적인 감염증상을 보였다(Fig. 6). S. iniae를 사용하여 감염시킨 경우, 대조구에서는 감염 후 23 일째까 지 $50 \%$ 의 누적폐사율을 보였으며, 발효마늘분말 $0.5 \%, 2 \%$ 그룹 에서는 각각 $40 \%, 10 \%$ 의 누적폐사율을 보였고, 발효마늘분말 $0.5 \%, 2 \%$ 그룹에서는 각각 $40 \%, 10 \%$ 의 누적폐사율을 나타내어 
Table 3. Growth performance of juvenile olive flounder fed the experimental diets for 5 weeks ${ }^{1)}$

\begin{tabular}{lcccc}
\hline Diets & G-0 & G-0.5 & G-1 & G-2 \\
\hline \hline IMW $^{2)}$ & $23.5 \pm 0.05$ & $23.5 \pm 0.06$ & $23.4 \pm 0.04$ & $23.5 \pm 0.05$ \\
FMW $^{3)}$ & $33.6 \pm 1.24$ & $31.5 \pm 1.58$ & $31.4 \pm 1.30$ & $31.9 \pm 1.06$ \\
Weight gain $^{4)}$ & $43.4 \pm 5.22$ & $34.1 \pm 6.83$ & $34.5 \pm 5.36$ & $35.8 \pm 4.40$ \\
FI $^{5)}$ & $17.5 \pm 0.62^{\mathrm{b}}$ & $16.7 \pm 0.92^{\mathrm{ab}}$ & $16.4 \pm 0.59^{\mathrm{ab}}$ & $16.0 \pm 0.51^{\mathrm{a}}$ \\
SGR $^{6}$ & $1.29 \pm 0.13$ & $1.04 \pm 0.18$ & $1.06 \pm 0.14$ & $1.09 \pm 0.12$ \\
FCR $^{7)}$ & $1.70 \pm 0.15$ & $2.12 \pm 0.35$ & $2.06 \pm 0.27$ & $1.93 \pm 0.19$ \\
PER $^{8)}$ & $1.30 \pm 0.11$ & $1.09 \pm 0.16$ & $1.11 \pm 0.14$ & $1.19 \pm 0.12$ \\
Survival & $75.6 \pm 6.9$ & $76.7 \pm 3.33$ & $78.9 \pm 1.9$ & $78.9 \pm 5.01$ \\
\hline
\end{tabular}

\footnotetext{
1) Means of triplicate groups; values are presented as mean $\pm \mathrm{SD}$.

2) $\mathrm{IMW}=$ Initial mean body weight.

3) $\mathrm{FMW}=$ Final mean body weight.

4) Weight gain $(\%)=100 \times($ final mean body weight - initial mean body weight $) /$ initial mean body weight.

${ }^{5)}$ Feed intake $(\mathrm{g} / \mathrm{g}$ body weight $)=$ dry feed fed $(\mathrm{g}) /$ body weight $(\mathrm{g})$.

6) Specific growth rate $(\%)=\left[\left(\log _{\mathrm{e}}\right.\right.$ final body weight $-\log _{\mathrm{e}}$ initial body weight $) /$ days $] \times 100$.

${ }^{7)}$ Feed conversion ratio $=$ dry feed fed/wet weight gain.

8) Protein efficiency ratio = wet weight gain/ total protein fed.
}

(A)

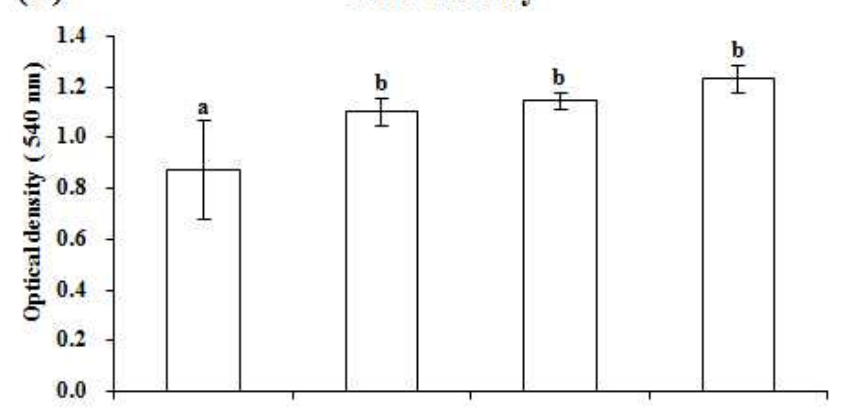

(C)

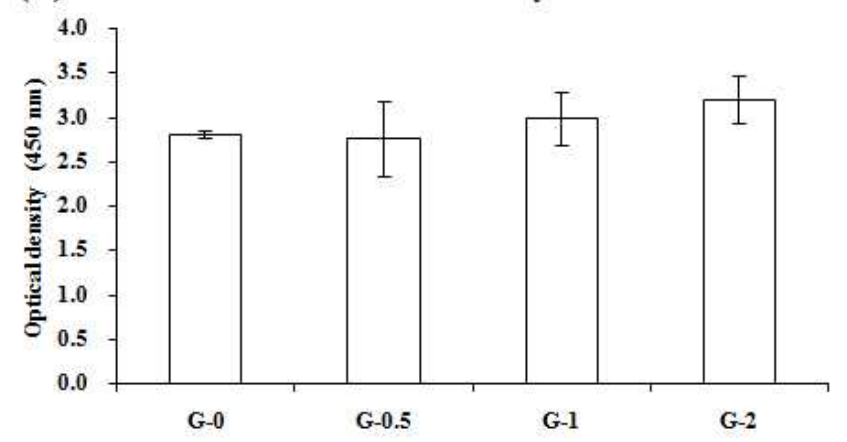

Experimental diets
(B) Lysozyme activity

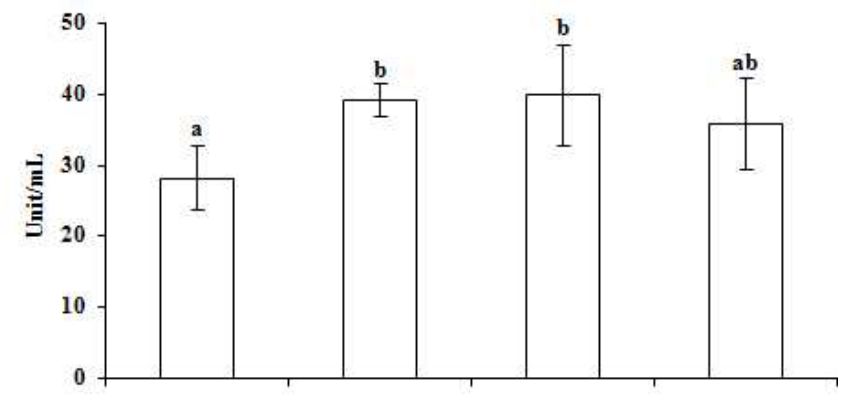

(D) ${ }_{120} \quad$ HDL-cholesterol

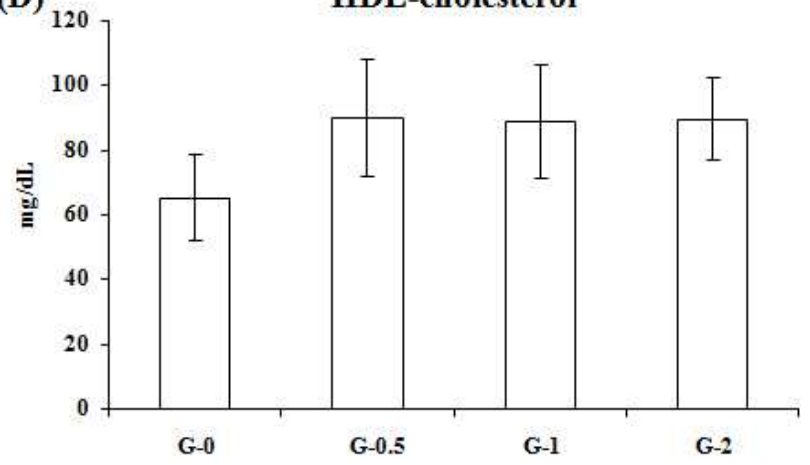

Experimental diets

Fig. 1. Nitroblue tetrazolium (NBT) actitivity (A), lysozyme activity (B), myeloperoxidase activity (C) and HDLcholesterol $(D)$ in fish fed the experimental diets containing different levels of fermentation garlic powder $0 \%, 0.5 \%, 1 \%$ and $2 \%(G \quad, G 0.5, G 1$ and $G 2)$ for 5 weeks. Values are means of triplicate per treatment. Bars with different letters are significantly different $(P<0.05)$. 
(A)

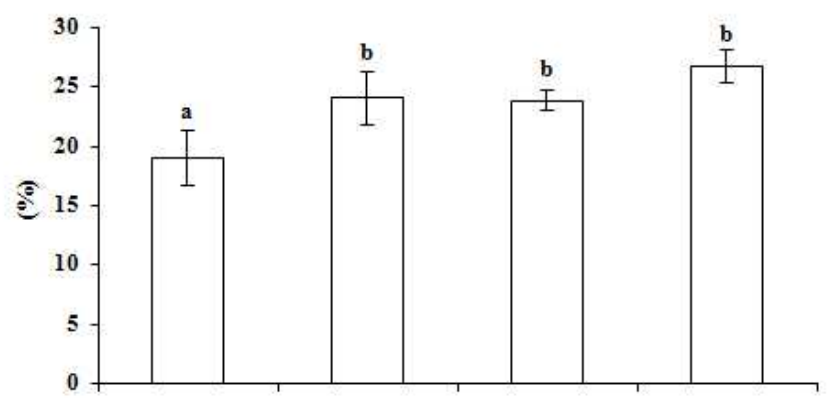

(C)

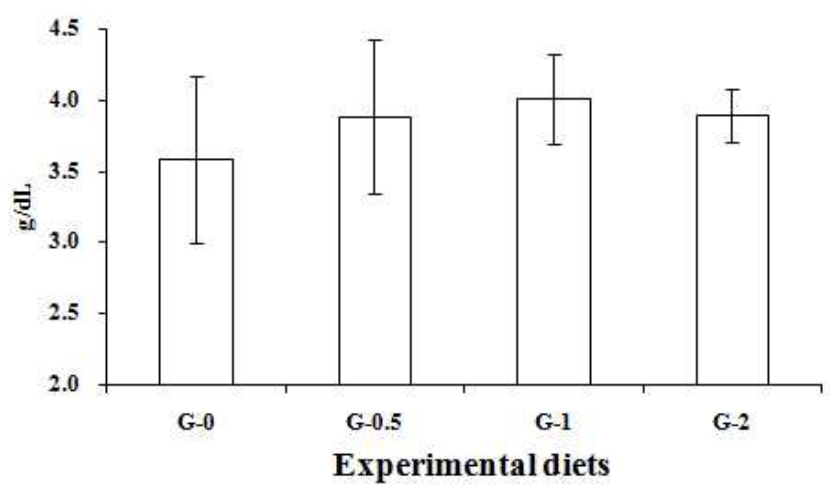

(B)

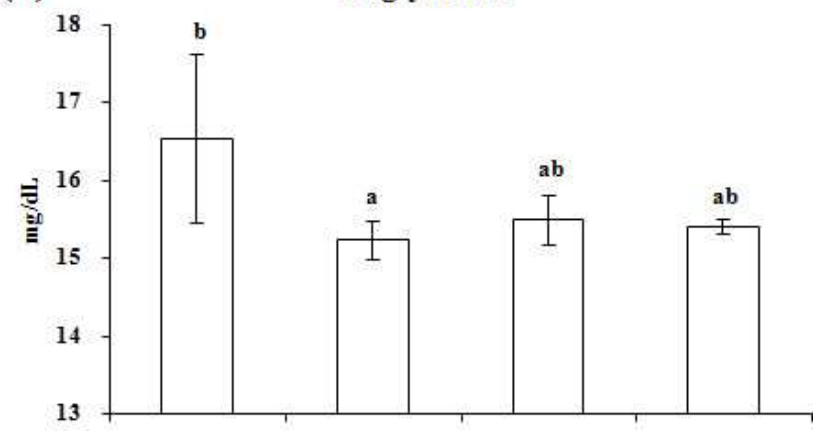

(D)

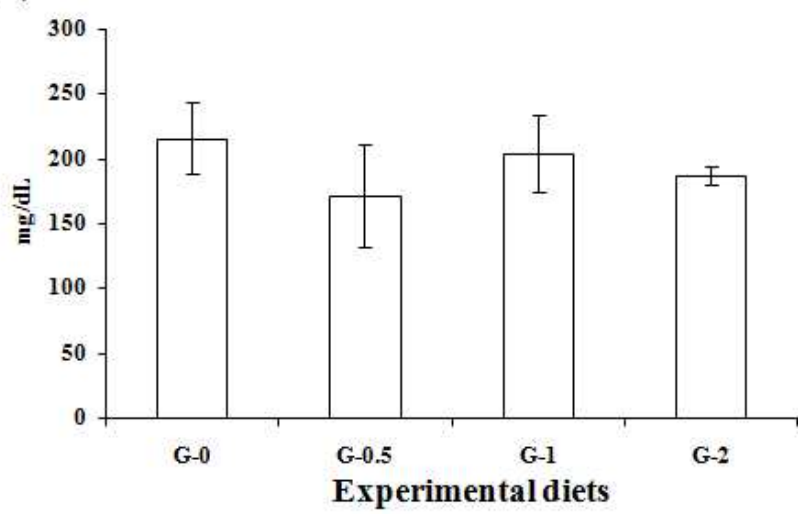

Fig. 2. Hematocrit (A), triglyceride (B), hemoglobin (C) and total cholesterol $(D)$ in fish fed the experimental diets containing different levels of fermentation garlic powder $0 \%, 0.5 \%, 1 \%$ and $2 \%$ (G $0, G 0.5, G 1$ and $G$ 2) for 5 weeks. Values are means of triplicate per treatment. Bars with different letters are significantly different $(P<0.05)$.

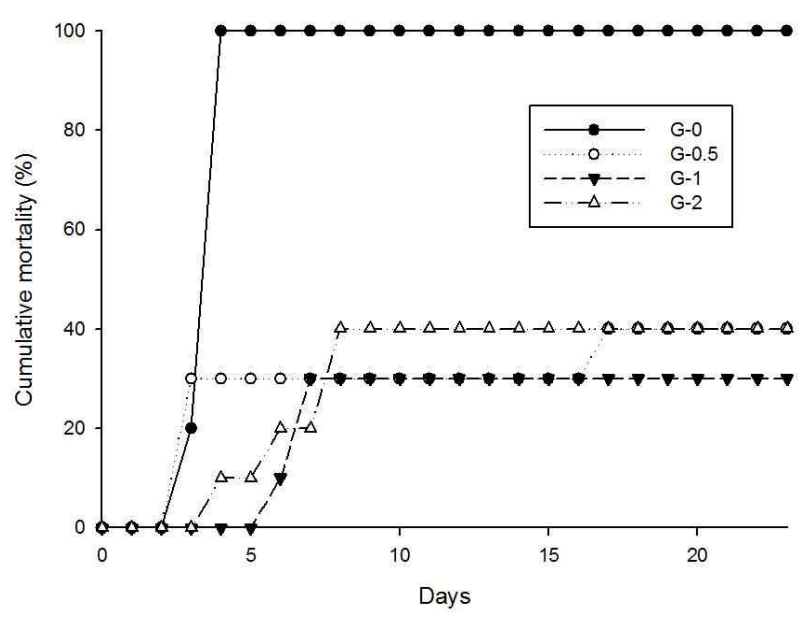

Fig. 3. Cumulative mortality of olive flounder fed the experimental diets containing $0 \%, 0.5 \%, 1 \%$ and $2 \%$ of fermentation garlic powder after challenge with Vibrio anguillarum by intraperitoneal injection.

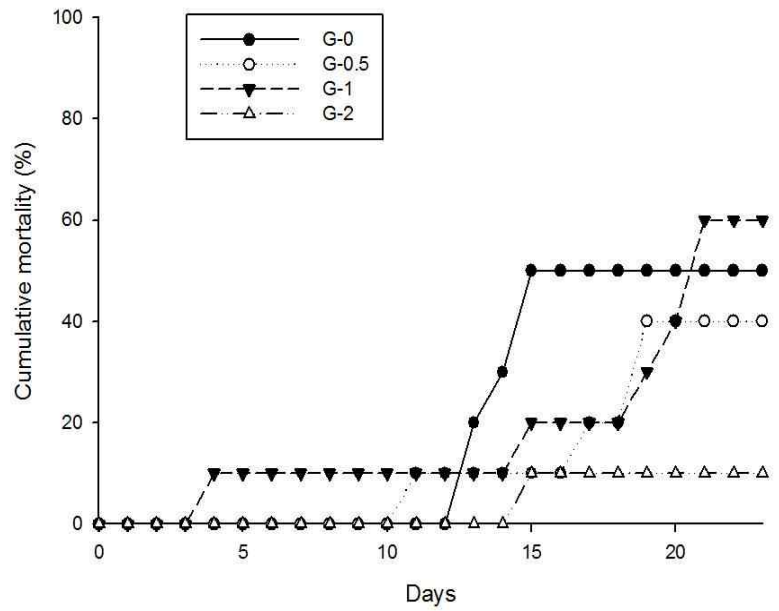

Fig. 4. Cumulative mortality of olive flounder fed the experimental diets containing $0 \%, 0.5 \%, 1 \%$ and $2 \%$ of fermentation garlic powder after challenge with Streptococcus iniae by intraperitoneal injection. 


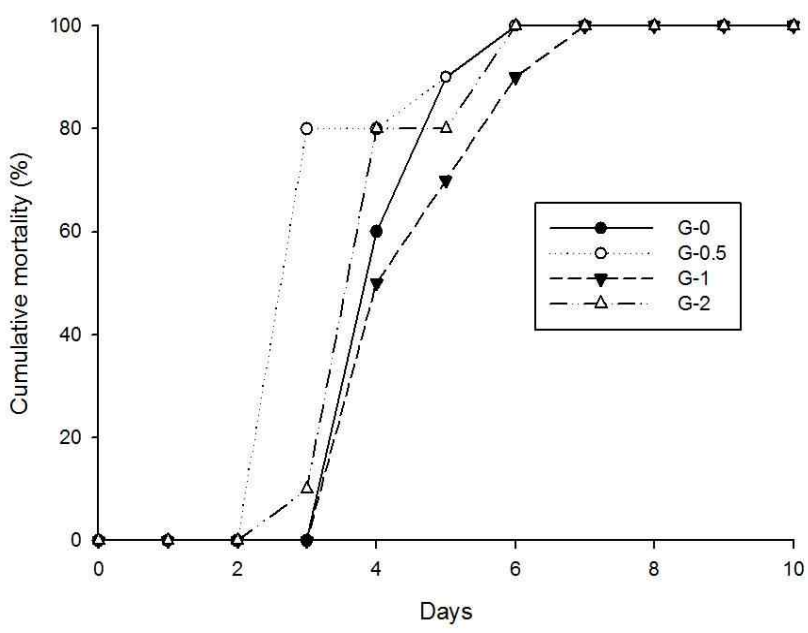

Fig. 5. Cumulative mortality of olive flounder fed the experimental diets containing $0 \%, 0.5 \%, 1 \%$ and $2 \%$ of fermentation garlic powder after challenge with Edwardsiella tarda by intraperitoneal injection.

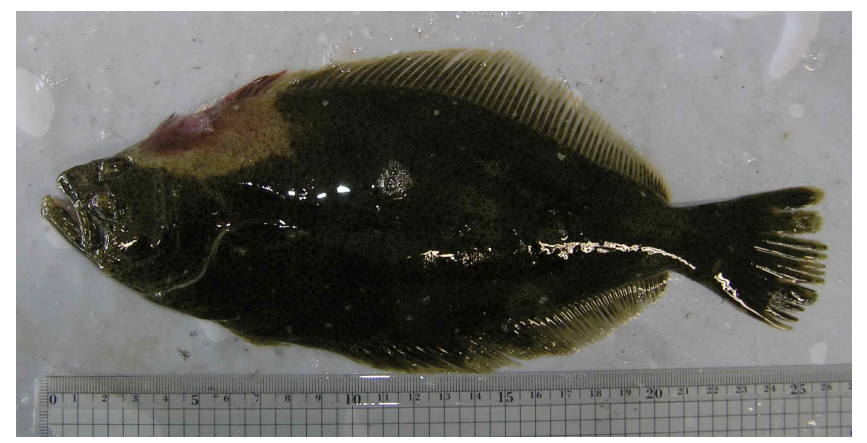

Fig. 6. An outbreak of Vibrio anguillarum infection of olive flounder from this study.

대조구보다 낮은 폐사율을 보였지만, 발효마늘분말 $1 \%$ 그룹에서는 $60 \%$ 로 대조구보다 높은 누적폐사율을 나타내었다 (Fig. 4). E. $\operatorname{tarda}$ 를 사용하여 감염시킨 경우, 감염 후 7일 이내에 모든 실험구 에서 $100 \%$ 누적 폐사하였으며, 대조구와 유의적인 차이를 보이지 않았다(Fig. 5).

\section{고 찰}

이 연구에서는 저수온기에 사료 내 발효마늘분말을 단계별로 첨 가하여 넙치 치어에 공급한 결과, 성장률, 일간성장률, 사료전환효 율, 단백질전환효율 및 생존율에 아무런 영향을 미치지 않았다. 그 러나 성장률에 있어서 발효마늘분말 첨가구가 대조구보다 감소하는 경향을 보였다. 또한 사료섭취율에서 마늘함량이 증가함에 따라 감 소하다가 가장 높은 $2 \%$ 실험구에서는 유의적으로 낮은 사료섭취율
을 보였다(Table 3). 황(1987)은 마늘이 면역반응에 미치는 영향 을 알아보고자 생쥐를 대상으로 수행한 결과, 생마늘 $2 \%$, 가열 처 리한 마늘 $2 \%$ 첨가시 식이섭취량이 저하됨을 보고하였고, 주 (1978)는 마늘농도 $0.5 \%, 1 \%, 2 \%$ 및 $3 \%$ 수준에서는 식이섭취량 이 대조구와 비슷하였고 $4 \%$ 첨가시 식이섭취량이 대조군 보다 훨 씬 저하됨을 보고하였다. Kwon et al. (2005)은 포유자돈과 이유자 돈을 대상으로 약용식물(인진쑥, 오가피 및 마늘)을 첨가하여 실험 한 결과 일당증체량과 사료효율에서는 약용식물을 첨가함으로써 증 가하는 경향을 보였으며, 사료섭취량에서는 감소하는 경향을 보였 다고 보고하였다. 하지만 육계 사료 내 마늘분말을 첨가한 결과 $3 \%$ 및 $5 \%$ 를 첨가한 처리구에서 유의적으로 높은 증체량을 보였 으나 사료섭취량은 처리구간 차이가 없었다(You et al., 2009). 본 연구에서는 마늘이 가지고 있는 향과 생리활성물질이 섭취율에 영 향을 미치는 것으로 판단된다. 수온은 어류의 성장에 영향을 미치 는 중요한 환경인자 중에 하나이며 (Brett and Higgs, 1970), 사육 수온이 증가함에 따라 사료섭취율은 증가하는 경향을 보인다 (Iwata et al., 1994; NRC 1993). 본 연구는 수온이 $16^{\circ} \mathrm{C}$ 에서 18 ${ }^{\circ} \mathrm{C}$ 범위인 저수온기에 수행되었다. 따라서 발효마늘분말 $2 \%$ 첨가 구에서 대조구보다 유의적으로 낮은 섭취율을 보인것은 사육수온, 발효마늘분말에 포함된 생리활성 물질 및 마늘의 향 등이 복합적으 로 작용한 것으로 판단된다. 하지만 보다 더 구체적인 매커니즘은 장기간의 성장실험과 발효마늘분말의 성분분석을 통한 충분한 해석 이 필요할 것으로 사료된다.

이미 많은 연구자들에 의해 마늘 첨가식이에 의한 혈청 콜레스테 롤과 중성지질의 저하효과는 증명되었다 (Sharma et al., 1976). Chun and Paik (1997)은 자발성 고혈압쥐를 대상으로 콜레스테롤, 중성지질, HDL-cholesterol을 조사한 결과, 대조군이 마늘첨가구 보다 높은 콜레스테롤 함량을 나타내었고, 중성지질에서는 낮은 경 향을 보였으나 유의적인 차이를 보이지 않았으며, $\mathrm{HDL}-$ cholesterol은 마늘 3\% 첨가군에서 대조군에 비해 다소 높은 경향 을 보였으나 유의적인 차이는 없다고 보고하였다. Qureshi (1983) 는 마늘식이 급여에 의해 중성지질은 감소하였으나 $\mathrm{HDL}-$ cholesterol 수준은 변화가 없다고 보고하였다. 본 연구에서도 발효 마늘분말의 첨가에 의해 중성지질은 감소하였으나, 콜레스테롤과 HDL-cholesterol 수준은 변화가 없었다. 본 연구의 결과와 지금까 지 수행된 여러 연구결과를 종합해 볼 때, 사료 내 마늘분말의 첨 가는 넙치 치어의 혈청 지질변화에 미치는 효과는 중성지질 수준을 감소시키는 것으로 사료된다(Fig. 2B).

사료 내 발효마늘분말이 비특이적 면역반응에 어떠한 영향을 미 치는지 알아보기 위하여 NBT, lysozyme 및 MPO activity를 측 정한 결과, 이번 연구에서는 대체적으로 발효마늘분말이 어류의 비 특이적 면역반응을 증진시키는 것으로 나타났다. 어류의 외부병원 체에 대한 방어시스템은 포유동물에서 밝혀진 것과 비슷하다. 우선 면역체계는 외부의 항원에 대하여 항체를 생산하여 대응하는 기작 을 가지고 있다. Mun et al. (2004)은 마늘을 첨가한 복합배지에서 배양된 영지버섯 균사체가 면역세포의 생육을 증진시키고 cytokine 
분비를 증진시키며, 항암활성을 증가시킨다고 보고하였다. 인간의 면역세포 중 하나인 $\mathrm{T}$ 세포의 생육을 증진시킨다는 것이다. 인간의 면역체계는 외부의 항원이 침입하면 면역체계가 활성화 되면서 항 원이 침입하여 발생하는 암과 같은 질병발생에 대하여 활성화된 면 역세포에 의하여 궁극적으로 항암활성이 나타난다. 따라서 본 연구 에서도 마늘의 생리활성 물질이 사료를 통하여 효과적으로 전달됨 으로서 어류의 면역체계를 활성화 시킨 것으로 판단된다.

발효마늘분말이 넙치 치어의 항병력에 미치는 영향을 분석하기 위한 세균 공격실험 결과, V. anguillarum에 대한 질병저항성이 현저히 증가하는 것으로 확인되었다. Kim et al. (2006)은 넙치를 대상으로 상황버섯과 운지버섯 균사체 배양액을 사료에 첨가하여 공급한 후, V. anguillarum로 공격실험을 하였을 때, 대조구에 비 해 약 $40 \%$ 정도의 높은 상대생존율 차이를 보였다고 보고하였다. 그 매커니즘으로 상황버섯과 운지버섯 균사체 배양액에 포함된 다 당류에 의한 라이소자임의 활성 또는 식세포의 활성 때문이라고 설 명하고 있다. 본 연구에서도 비 특이적 면역반응을 분석한 결과 마 늘첨가 실험구에서 NBT activity와 lysozyme activity가 유의적으 로 증가되었다. 따라서 마늘에 포함된 유용 생리활성물질에 의한 면역시스템의 활성으로 항병력이 증가된 것으로 사료된다. S. iniae 의 경우, 대조구에서는 공격실험 후 13 15일 사이에 폐사가 집중 적으로 나타나는데 반하여, $1 \%$ 그룹에서는 $15 \sim 21$ 일 사이에 대부 분의 폐사가 발생하여 전체적인 폐사 시기가 대조구에 비해 지연되 는 것을 확인하였다. Pham et al. (2006)은 넙치를 대상으로 톳 (Hizikia fusiformis)을 사료에 첨가하여 공급한 후, S. iniae로 공 격실험을 하였을 때, 톳을 단계적으로 첨가함에 따라 누적사망률이 감소하다가 가장 높은 $6 \%$ 첨가 그룹에서는 폐사가 일어나지 않았 다고 보고하였다. 그 매커니즘으로는 톳의 첨가로 인한 실험사료의 폴리페놀함량의 증가와 NBT activity 증가로 인한 면역력 증가라 고 보고하였다. E. $\operatorname{tarda}$ 을 사용하여 감염시킨 경우, 모든 실험구 에서 공격실험 후 7 일 이내에 $100 \%$ 누적 폐사하였으며, 대조구와 유의적인 차이를 보이지 않았다. Cho et al. (2006)은 넙치를 대상 으로 녹차를 사료에 첨가하여 공급한 후, E. $\operatorname{tarda}$ 로 공격실험을 하였을 때, 본 연구와 비슷하게 모든 실험구에서 유의적인 차이를 보이지 않았다. 따라서 사료 내 발효마늘분말의 첨가는 E. tarda에 대한 항병력에 효과가 없거나 E. $\operatorname{tarda}$ 의 주사농도가 적절하지 않 았을 것으로 추측된다. 공격실험의 결과를 종합하면, 사료 내 발효 마늘분말의 첨가는 $E . \operatorname{tarda}$ 를 제외한 나머지 병원체를 대상으로 한 실험에서는 마늘 섭취에 의해 넙치의 항병력이 증가되었음을 확 인할 수 있었다. 특히 V. angullarum에 대한 항병력이 가장 우수 한 것으로 확인할 수 있었다. 이러한 결과는 마늘에 함유되어 있는 여러 가지 유용 생리활성물질에 의해서 사료 자체의 항산화효과가 증가하여, 실험사료를 섭취한 어류에 효과적으로 전달됨으로서 라 이소자임의 활성 또는 식세포의 활성에 영향을 주어 비특이적 면역 반응을 증강시킨 것으로 판단된다.

이상의 모든 결과를 종합해 볼 때, 사료 내 발효마늘분말의 첨가 는 저수온기 넙치 치어에 있어서 비특이적 면역반응을 증진시켜 주
요 어병세균인 $V$. anguillarum 및 S. iniae에 대한 항병력을 향상 시켰다. 하지만 E. tarda에 대한 항병력에는 효과가 나타나지 않았 다. 또한 사료섭취율이 첨가 농도가 증가함에 따라 감소하였고, 가 장 높은 $2 \%$ 첨가구에서는 유의적으로 감소하였다. 본 연구는 저수 온기에 발효마늘분말의 효과를 검증하기 위해 5 주간의 단기적인 성장실험을 수행하였다. 따라서 보다 장기적인 성장실험을 통해 성 장률, 일간성장률, 단백질전환효율, 사료전환효율 및 먹이섭취율에 대한 재조명이 필요할 것으로 판단된다. 또한 앞으로 마늘분말의 현장적용 및 산업화를 위해서는 양식 환경 (수온, 밀도 등), 투여 기간, 농도, 성분 분석 등과 같은 보다 세부적인 연구가 추가적으 로 수행되어져야 할 것으로 사료된다.

\section{요 약}

우리 연구팀은 넙치를 대상으로 사료 내 발효마늘분말 (fermented garlic powder, FGP)의 첨가에 의한 비특이적 면역반 응과 어병세균(V. anguillarum, S. iniae, E. tarda)에 대한 질병 저항성에 대해 처음으로 보고한다. 동일한 단백질 함량 $(45 \%)$ 과 칼 로리 $(17.1 \mathrm{MJ} / \mathrm{kg})$ 를 갖은 4 개의 실험사료는 발효마늘분말이 $0 \%$, $0.5 \%, 1 \%$ 및 $2 \%(\mathrm{G}-0, \mathrm{G}-0.5, \mathrm{G}-1$ 및 $\mathrm{G}-2)$ 가 포함되도록 조성 되었다. 실험은 3 반복구로 수조 당 30 마리의 어류를 대상으로 유 수식 시스템에서 수행되었다. 5주간의 성장실험 종료 후, 각 수조 에서 건강한 어류를 선별하여 어류의 항병력을 평가하기 위해 3 가 지 박테리아 부유액 $(1 \mathrm{ml})$ 을 복강에 주사하였다. 5 주간의 성장실험 기간 동안에 성장률, 일간성장률, 사료전환효율, 단백질전환효율 및 생존율에서는 실험사료에 의한 유의적인 차이가 없었다. 그러나 사 료섭취율은 발효마늘분말이 $2 \%$ 첨가된 그룹에서 대조구와 비교하 여 유의적으로 낮았다. 헤모글로빈, 헤마토크릿, 대식세포 활성 및 라이소자임 활성에서는 사료 내 발효마늘분말 함량이 증가함에 따 라 유의적으로 증가하였다. 발효마늘분말 $0.5 \%$ 첨가구의 혈장 중 성지질은 대조구보다 유의적으로 낮았다. 누적사망률은 E. $\operatorname{tarda}$ 의 경우를 제외한 모든 공격실험에서 발효마늘분말이 포함된 사료를 섭취한 어류가 대조구와 비교하여 유의적으로 낮았다. 이번 연구의 결과를 볼 때, 사료 내 발효마늘분말의 첨가는 넙치에 있어서 $V$. anguillarum과 S. iniae에 대한 항병력 및 비특이적 면역반응을 향 상시킨 것으로 사료된다.

\section{사 사}

이 논문은 농림수산식품부 수산기술개발사업 (친환경 유기양식 생산 매뉴얼 개발을 통한 양식넙치의 고품질화 및 가공기술 개발, 과제번호: F20815308H220000110)의 연구비 지원과 2008년도 정 부 (교육과학기술부)의 재원으로 한국연구재단의 지원을 받아 수행 된 연구(No. 2008-0059211)이며, 이에 감사드립니다. 


\section{인 용 문 헌}

AOAC. 1995. Official methods of analysis. 16th ed. Association of Official Analytical Chemists. Arlington, Virginia, 1-1298.

Brett, J. R. and Higgs, D. A. 1970. Effects of temperature on rate of gastric digestion in fingerling sockeye salmon, Oncorhynchus nerka. J. Fish. Res. Bd. Can. 27, 1767-1779.

Chi, M. S., Koh, E. T. and Stewart, T. J. 1982. Effect of garlic on lipid metabolism in rats fed cholesterol or lard. J. Nutr. 112, 241-248.

Cho, S. H., Lee, S. M., Park, B. H., Ji, S. C., Kwon, M. G., Kim, Y. C., Lee, J. H., Park, S. and Han, H. K. 2006. Effect of dietary inclusion of various sources of green tea on immune system and challenging test of juvenile olive flounder Paralichthys olivaceus. J. of Aquaculture. 19, 84-89.

Chun, H. J. and Paik, J. E. 1997. Effect of heat treatment of garlic added diet on the blood of spontaneously hypertension rat. $\mathrm{J}$. Korean Soc. Food Sci. Nutr. 26, 103-108.

Chung, J. Y. and Kim, C. S. 2008. Antioxidant activities of domestic garlic (Allium sativum L.) stems from different areas. J. Korean Soc. Food Sci. Nutr. 37, 972-978.

Folch, J., Lee, M. and Sloane-Stanley, G. H. 1959. A simple method for the isolation and purification of total lipids from animal tissues. J. Biol. Chem. 226, 497-509.

Garling, D. L. J. and Wilson, R. P. 1976. Optimum dietary protein to energy ratio for channel catfish fingerlings, Ictalurus punctatus. J. Nutr. 106, 1368-1375.

Iwata, N., Kikuchi, K., Honda, H., Kiyono, M. and Kurokura, H. 1994. Effects of temperature on the growth of Japanese flounder. Fish. Sci. 60, 527-531.

Kim, K. J., Do, J. R. and Kim, H. K. 2005. Antimicrobial, antihypertensive and anticancer activities of garlic extracts. Korean J. Food Sci. Technol. 37, 228-232.

Kim, M. J., Kim, M. C., Kim, T., Kim, K. Y. and Heo, M. S. 2006. Effect of dietary supplementation of extracts of mushroom mycelium on survival and growth of juvenile flounder, Paralichthys olivaceus. J. of Aquaculture. 19, 231-235.

Kim, S. S., Galaz, G. B., Lee, K. J. and Lee, Y. D. 2006. Effects of dietary supplementation of Spirulina and astaxanthin for juvenile olive flounder, Paralichthys olivaceus in low temperature season. J. of Aquaculture. 19, 57-63.

Kim, Y. D., Kim, K. M., Hur, C. K., Kim, E. S., Cho, I. K. and Kim, K. J. 2004. Antimicrobial activity of garlic extracts according to different cooking methods. Korean Journal of Food Preservation. 11, 400-404.

Kumari, J. and Sahoo, P. K. 2005. Seasonal variation in the innate immune parameters of the Asian catfish Clarias batrachus. Aquaculture. 252, 121-127.

Kwon, O. S., Yoo, J. S., Min, B. J., Son, K. S., Cho, J. H., Kim, H. J., Chen, Y. J. and Kim, I. H. 2005. Effect of supplemental medicinal plants (Artemisia, Acanthopanax and Garlic) on growth performance and serum characteristics in lactating sows, suckling and weanling pigs. J. Anim. Sci. \& Technol. (Kor.) 47, 501-512.

Mazelis, M. and Crews, L. 1968. Purification of the alliin lyase of garlic, Allium sativum L. Biochem. J. 108, 725-730.

Mun, H. Y., Lee, H. S., Park, J. H., Kim, D. H., Lee, S. Y., Seong, N. S., Bang, J. K., Jung, H. G. and Lee, H. Y. 2004. Enhancement of immune activities of Ganoderma lucidum mycelium cultured with garlic enriched medium. Korean J. Medicinal Crop. Sco. 12, 24-30.

NRC (National Research Council), 1993. Nutrient Requirements of fish. National Academy Press, Washington DC, 114 pp.

Park, K. Y., Lee, S. J., Lee, K. I. and Rhee, S. H. 2005. The antitumor effect in Sarcoma-180 tumor cell of mice administered with japanese apricot, garlic or ginger Doenjang. Korean J. Food Cookery Sci. 21, 599-606.

Pham, M. A., Lee, K. J., Lee, B. J., Lim, S. J., Kim, S. S., Lee, Y. D., Heo, M. S. and Lee, K. W. 2006. Effects of dietary Hizikia fusiformis on growth and immune responses in juvenile olive flounder (Paralichthys olivaceus). Asian-Aust. J. Anim. Sci. 19, 1769-1775.

Qureshi, A. 1983. Suppression of avian hepatic lipid metabolism by solvent extracts of garlic : Impact on serum lipids. J. Nutr. 113, 1746-1755

Sharma, K. K., Sharma, A. L., Dwivedi, K. K. and Sharma, P. K. 1976. Effect of raw and boiled garlic on blood cholesterol in butter fat lipidemia. The Ind. J. Nutr. Dietet. 13, 7-11.

Shin, J. H., Jung, K. M., Lee, S. J., Yang, S. M., Rue, G. H. and Sung, N. J. 2009. Biological activities of dried garlic, red ginseng and their mixture. J. Korean Soc. Food Sci. Nutr. 38, 1633-1639.

Shon, H. E., Lee, J. Y., Kim, D. C. and Hwang, W. I. 2001. Enhancement of anticancer activity by combination of garlic (Allium sativum) extract and vitamin C. J. Korean Soc. Food Sci. Nutr. 30, 372-376.

Small, L. D., Bailey, J. H. and Cavallito, C. J. 1947. Alkyl thiosulfinates. J. Am. Chem Soc. 69, 1710-1713.

Stoll, A. and Seebeck, E. 1951. Chemical investigations of alliin, and the specific principle of garlic. Adv. Enzymol. 11, 377-340.

Wi, S. U. 2003. Isolation of alliin in garlic and its quantitative determination by high performance liquid chromatography and studies on the antimicrobial effects of alliin and ethanol extracts 
from korean garlic (Alliium sativum L.). Korean J. Food \& Nutr. $16,296-302$.

Yeh, S. P., Chang, C. A., Chang, C. Y., Liu, C. H. and Cheng, W. 2008. Dietary sodium alginate administration affects fingerling growth and resistance to Streptococcus $s p$. and iridovirus, and juvenile non-specific immune responses of the orange-spotted grouper, Epinephelus coioides. Fish and Shellfish immunology, 25, 19-27.

You, S. J., Anh, B. K. and Kang, C. W. 2009. Effects of dietary garlic powder on growth performance and mRNA expression of hepatic HMG-CoA reductase in broiler chickens. J. Anim. Sci. \& Technol. (Kor) 51, 307-314.

주은정. 1978. 마늘의 첨가급식이 백서의 성장 및 장기중 성분함량에 미치 는 영향. 숙명여자대학교 석사학위논문.

황영식. 1987. 마우스에 있어서 면역반응에 미치는 마늘효과. 원광대학교 박사학위논문.

(접수일자 : 2010. 4. 20 / 수정일자: 2010. 5. 24 / 채택일자 : 2010. 7. 19) 